\title{
Clouds, photolysis and regional tropospheric ozone budgets
}

\author{
A. Voulgarakis ${ }^{1, *}$, O. Wild ${ }^{2}$, N. H. Savage ${ }^{3}$, G. D. Carver ${ }^{1}$, and J. A. Pyle ${ }^{1}$ \\ ${ }^{1}$ Centre for Atmospheric Science, University of Cambridge, UK \\ ${ }^{2}$ Lancaster Environment Centre, Lancaster University, UK \\ ${ }^{3}$ Met Office, Exeter, UK \\ * now at: the NASA Goddard Inst. for Space Studies \& Columbia Univ., Center for Climate Systems Res., New York, USA
}

Received: 9 April 2009 - Published in Atmos. Chem. Phys. Discuss.: 25 June 2009

Revised: 29 September 2009 - Accepted: 19 October 2009 - Published: 3 November 2009

\begin{abstract}
We use a three-dimensional chemical transport model to examine the shortwave radiative effects of clouds on the tropospheric ozone budget. In addition to looking at changes in global concentrations as previous studies have done, we examine changes in ozone chemical production and loss caused by clouds and how these vary in different parts of the troposphere. On a global scale, we find that clouds have a modest effect on ozone chemistry, but on a regional scale their role is much more significant, with the size of the response dependent on the region. The largest averaged changes in chemical budgets $( \pm 10-14 \%)$ are found in the marine troposphere, where cloud optical depths are high. We demonstrate that cloud effects are small on average in the middle troposphere because this is a transition region between reduction and enhancement in photolysis rates. We show that increases in boundary layer ozone due to clouds are driven by large-scale changes in downward ozone transport from higher in the troposphere rather than by decreases in in-situ ozone chemical loss rates. Increases in upper tropospheric ozone are caused by higher production rates due to backscattering of radiation and consequent increases in photolysis rates, mainly $\mathrm{J}\left(\mathrm{NO}_{2}\right)$. The global radiative effect of clouds on isoprene, through decreases of $\mathrm{OH}$ in the lower troposphere, is stronger than on ozone. Tropospheric isoprene lifetime increases by $7 \%$ when taking clouds into account. We compare the importance of clouds in contributing to uncertainties in the global ozone budget with the role of other radiatively-important factors. The budget is most sensitive to the overhead ozone column, while surface albedo and clouds have smaller effects. However, uncertainty in representing the spatial distribution of clouds may lead to a large sensitivity of the ozone budget components on regional scales.
\end{abstract}

Correspondence to: A. Voulgarakis (avoulgarakis@giss.nasa.gov)

\section{Introduction}

The main factors affecting atmospheric radiative transfer at wavelengths important for tropospheric chemistry are the solar zenith angle, absorption by stratospheric ozone, reflection from the surface, and scattering and absorption by cloud and aerosol particles. Uncertainty in the scattering and absorption terms is relatively high, making assessment of their role in the Earth's chemistry-climate system challenging. In particular, treatment of clouds remains one of the largest sources of uncertainty in simulating atmospheric composition (IPCC, 2007). Uncertainty in cloud properties and coverage contributes to the large range in ozone production and loss rates $\left(\mathrm{P}\left(\mathrm{O}_{3}\right)\right.$ and $\left.\mathrm{L}\left(\mathrm{O}_{3}\right)\right)$ simulated by chemical models. In addition, clouds are likely to change in a future climate, and thus their role in influencing tropospheric oxidizing capacity needs to be understood.

Previous studies have found that the global annual average net chemical production of ozone decreases by $15 \%$ at the surface and increases by $15 \%$ in the upper troposphere when including clouds relative to clear sky conditions (Wild et al., 2000). However, there was only a small change (2.5\%) in the global ozone budget, and more recent studies have found similar results (Liu et al., 2006). The magnitude of these cloud effects varies significantly between models using different photolysis codes. For example, using the MOZART-2 model coupled with the FTUV photolysis scheme Tie et al. (2003b) found global ozone burden increases of $8-12 \%$ with clouds compared to clear-sky conditions, whereas Liu et al. (2006) found increases of 3-5\%. In their assessment of ozone budget uncertainties, Wu et al. (2007) showed that global tropospheric $\mathrm{P}\left(\mathrm{O}_{3}\right)$ in GEOS-CHEM varied significantly when using different meteorological fields and that clouds were the major cause of these variations.

The causes of variation in modelled ozone budgets have been examined in recent studies (Wu et al., 2007; Wild,

Published by Copernicus Publications on behalf of the European Geosciences Union. 
Table 1. Annual tropospheric ozone budgets for the reference run (REF) and the percentage difference compared to results from a run with no clouds (NOCL).

\begin{tabular}{lllllllll}
\hline & $\begin{array}{l}\mathrm{P}\left(\mathrm{O}_{3}\right) \\
\mathrm{Tg} \mathrm{yr}^{-1}(\%)\end{array}$ & $\begin{array}{l}\mathrm{L}\left(\mathrm{O}_{3}\right) \\
\mathrm{Tg} \mathrm{yr}^{-1}(\%)\end{array}$ & $\begin{array}{l}\text { Transp. } \\
\mathrm{Tg} \mathrm{yr}^{-1}(\%)\end{array}$ & $\begin{array}{l}\text { Dep. } \\
\mathrm{Tg} \mathrm{yr}^{-1}(\%)\end{array}$ & $\begin{array}{l}\text { Mean OH } \\
10^{5} \mathrm{molec} \mathrm{cm}^{-3}\end{array}$ & $\begin{array}{l}\mathrm{CO} \mathrm{Burden} \\
\mathrm{Tg}(\%)\end{array}$ & $\begin{array}{l}\mathrm{NO}_{\mathrm{x}} \mathrm{Burden} \\
\mathrm{Tg}(\%)\end{array}$ & $\begin{array}{l}\mathrm{O}_{3} \mathrm{Burden} \\
\mathrm{Tg}(\%)\end{array}$ \\
\hline Global & $5340(+0.2)$ & $4723(+0.4)$ & $741(-0.8)$ & $1380(-0.2)$ & $12.9(+0.9)^{1}$ & $297(+0.8)$ & $0.352(+2.6)$ & $367(+1.2)$ \\
$90 \mathrm{~N}, 20 \mathrm{~N}$ & $1828(-0.6)$ & $1320(-0.3)$ & $168(+0.1)$ & $682(-0.7)$ & $11.9(+0.0)$ & $92(+1.1)$ & $0.153(+2.7)$ & $129(+1.6)$ \\
$20 N, 20 \mathrm{~S}$ & $2807(+0.3)$ & $2689(+0.5)$ & $337(-0.9)$ & $468(-0.0)$ & $16.5(+0.9)$ & $136(+0.7)$ & $0.145(+2.8)$ & $127(+1.3)$ \\
$20 S, 90 \mathrm{~S}$ & $705(+2.0)$ & $714(+1.4)$ & $236(-1.3)$ & $230(+0.9)$ & $8.7(+2.4)$ & $69(+0.6)$ & $0.054(+1.9)$ & $109(+1.5)$ \\
\hline
\end{tabular}

${ }^{1}$ The full methane lifetime in the model (atmospheric burden of methane divided by total atmospheric loss including loss in the stratosphere and soils) is $6.85 \mathrm{yrs}$. It increased by $1.7 \%$ when adding clouds in the model. This is at the low end of the current best estimates of the average lifetime of 8.45 years (Stevenson et al., 2006), but reflects differences in the methane distribution used and neglect of aerosol interactions.

2007). $\mathrm{P}\left(\mathrm{O}_{3}\right)$ in global models simulating the present-day atmosphere varies from 2300 to $5300 \mathrm{Tg} / \mathrm{yr}$. Wild (2007) showed that almost two thirds of the increase in $\mathrm{P}\left(\mathrm{O}_{3}\right)$ in studies published over the past decade can be attributed to increased $\mathrm{NO}_{\mathrm{x}}$ and isoprene emissions, but that differences in stratosphere-troposphere exchange (STE), wet and dry deposition, humidity and lighting also contributed. By applying a multivariate linear regression analysis to an ensemble of 32 models, Wu et al. (2007) found that $74 \%$ of the variance of $\mathrm{P}\left(\mathrm{O}_{3}\right)$ can be explained by linear dependences on $\mathrm{NO}_{\mathrm{x}}$ emissions, NMVOC emissions and STE. However, increases in $\mathrm{P}\left(\mathrm{O}_{3}\right)$ do not necessarily lead to increases in the global ozone burden, as changes in loss rates and ozone transport may compensate for these.

These previous studies provide valuable insight into global cloud-chemistry interactions. However, they either examine the effect of clouds on tracer concentrations without examining chemical budgets (Tie et al., 2003b; Liu et al., 2006), or they explore the ozone budget thoroughly without evaluating the effects of clouds in detail (Wild, 2007; Wu et al., 2007). We extend this earlier work by focusing on how clouds contribute to the large uncertainties in the global ozone budget in current models through their effects on photolysis rates. In addition, we examine the radiative effect of perturbations to clouds, surface albedo and stratospheric ozone on tropospheric chemistry with sensitivity studies following Krol and VanWeele (1997), extending their approach to examine variations in $\mathrm{P}\left(\mathrm{O}_{3}\right)$ and $\mathrm{L}\left(\mathrm{O}_{3}\right)$ in more detail.

\section{Model description}

We use the Cambridge $p$-TOMCAT chemical transport model (CTM) as described in Voulgarakis et al. (2009). The CTM accounts for 63 chemical species, and isoprenerelated reactions are represented according to the method of Pöschl et al. (2000) as implemented by Young et al. (2008). Monthly-mean aerosol distributions are specified off-line from GOCART model simulations (Chin et al., 2002). Heterogeneous removal of $\mathrm{N}_{2} \mathrm{O}_{5}$ on sulfate aerosol is included following Tie et al. (2003a) with an updated treatment of the uptake coefficient based on Evans and Jacob (2005).

The CTM uses the Fast-JX photolysis scheme (Neu et al., 2007), and the cloud water content, cloud fractional coverage, and surface albedos used in the radiative transfer calculations are taken from the ECMWF analyses. Overlap of clouds in different layers is simulated according to the Approximate Random Overlap method as described in Voulgarakis et al. (2009). As demonstrated in Voulgarakis et al. (2009), the comparison of cloud optical depths used in this study with satellite data is satisfactory for a big part of the extratropical regions, but there are significant overestimations in the model over tropical regions. Overestimated tropical cloudiness was also found by Jakob (1999) when comparing the ECMWF cloud cover with satellite measurements. For simplicity, the aerosol distributions were not used in the radiative transfer calculations described here.

Previous studies have demonstrated that the model is capable of simulating ozone with a relatively small bias in the low and middle troposphere (Voulgarakis et al., 2009), although larger biases (up to $+45 \mathrm{ppbv}$ ) are present at higher altitudes, possibly due to the way that the upper boundary is treated or the lack of detailed stratospheric chemistry in the model (Law et al., 2000).

The net chemical production is diagnosed from model runs as the difference in the tropospheric ozone burden before and after the chemical integration step accumulated over the time period of interest. The net transport tendency (STE for the global case) is calculated from the difference in ozone burden before and after the call to the transport scheme. Dry deposition is diagnosed using the ozone burden for the bottom grid boxes of the model together with the first order loss rates due to this process. Ozone chemical production is estimated separately by adding the fluxes through the reactions of $\mathrm{NO}$ with $\mathrm{HO}_{2}, \mathrm{CH}_{3} \mathrm{O}_{2}$ and $\mathrm{RO}_{2}$ which oxidise $\mathrm{NO}$ to $\mathrm{NO}_{2}$; ozone loss is then diagnosed from the difference between the net chemical production and the production term. The tropopause is diagnosed as the $380 \mathrm{~K}$ isentropic surface in the tropics and the 3.5 PVU surface in the extratropics. 


\section{Ozone budgets and the large-scale shortwave radia- tive effect of clouds}

Two simulations were performed: a reference run (REF) using cloud data from the ECMWF meteorology, and another where clouds were removed completely (NOCL). The period of integration was 15 months (October 1996-December 1997) with the first three months taken as a spin-up.

In Table 1, the simulated ozone budgets are presented for the globe and for three different regions: the northern extratropics, the tropics and the southern extratropics. The numbers in parentheses indicate the percentage change caused by including clouds in the simulation. The global production and loss terms are very similar to those from the recent ACCENT model intercomparison (Stevenson et al., 2006) where average production and loss were found to be $5110 \pm 606 \mathrm{Tg} \mathrm{yr}^{-1}$ and $4668 \pm 727 \mathrm{Tg} \mathrm{yr}^{-1}$, respectively. Further analysis of the main characteristics of the ozone budget calculated with this version of $p$-TOMCAT is described in Voulgarakis et al. (2009).

The changes in the global, tropical and extra-tropical ozone budgets and species' burdens due to the effect of clouds are small, generally less than $\pm 3 \%$. The largest changes in the ozone budget occur in southern extratropical regions. Annual mean cloud water contents are generally higher in the southern than in the northern hemisphere, as seen in Fig. 1, which shows the zonal mean distribution of cloud water content and the effect on photolysis rates over the vertical extent of the troposphere. The overall effect of clouds on $\mathrm{P}\left(\mathrm{O}_{3}\right)$ and $\mathrm{L}\left(\mathrm{O}_{3}\right)$, and consequently on the transport and deposition terms, is more significant in the southern extratropics. Krol and VanWeele (1997) found that stratiform clouds are most important for photolysis due to their relatively high optical depths and high frequency of occurrence. This type of cloud is dominant in the southern hemisphere.

The larger effect of clouds in the southern hemisphere than in the rest of the globe is also reflected in $\mathrm{OH}$ concentrations which respond directly to changes in the ozone loss term $\left(\mathrm{O}_{3}+\mathrm{hv} \rightarrow \mathrm{O}^{1} \mathrm{D}+\mathrm{O}_{2}\right.$ leads to $\mathrm{OH}$ formation). Evidence for this almost linear dependence was shown by Rohrer and Berresheim (2006). The fate of $\mathrm{OH}$ following formation depends on a variety of factors, and one of the pathways includes its recycling, leading to sustained high concentrations, even in remote regions (Lelieveld et al., 2008; Hofzumahaus et al., 2009). For longer-lived species this hemispheric difference is not evident, as their abundances are affected significantly by transport, deposition, and more complex chemistry. For example, the ozone burden is affected by clouds more uniformly than $\mathrm{OH}$.

The change in the methane lifetime due to the radiative effect of clouds is small $(+1.7 \%)$. This increase in methane lifetime occurs even though mean $\mathrm{OH}$ concentrations increase by $+0.9 \%$, an effect also noted by Liu et al. (2006). The oxidation of methane by $\mathrm{OH}$ is faster near the Earth's surface, so reductions in boundary layer $\mathrm{OH}$ caused a) Water Content

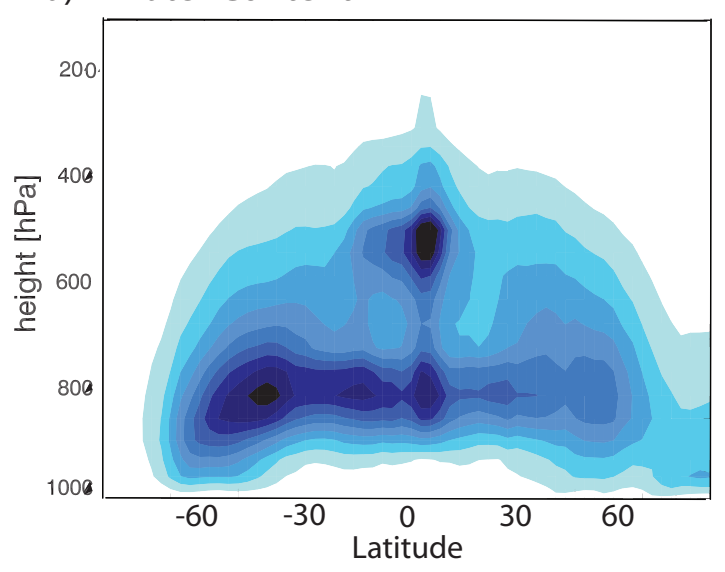

$(\mathrm{Kg} / \mathrm{Kg}) \times 10^{5}$

b) $\mathrm{J}\left(\mathrm{NO}_{2}\right)$

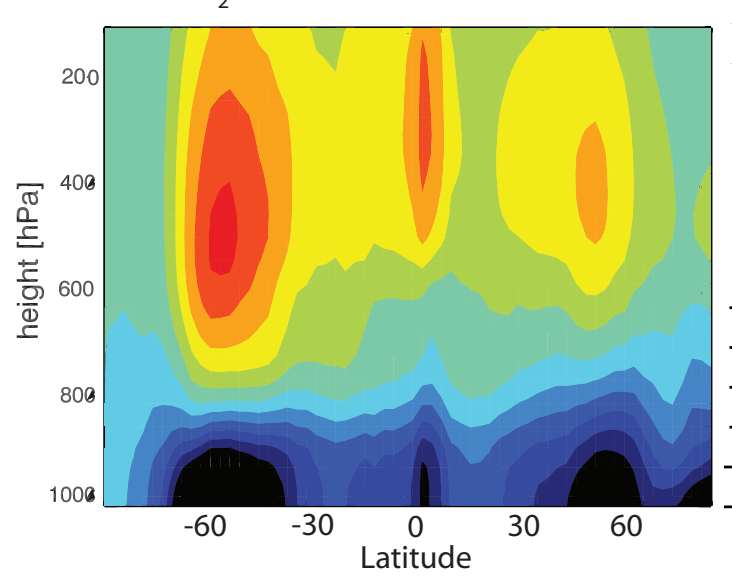

Diff [\%]

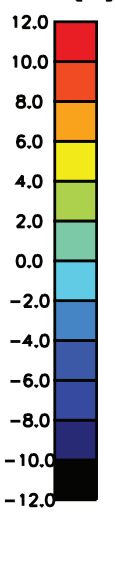

c) $\mathrm{J}\left(\mathrm{O}_{3}{ }^{1} \mathrm{D}\right)$

Diff [\%]

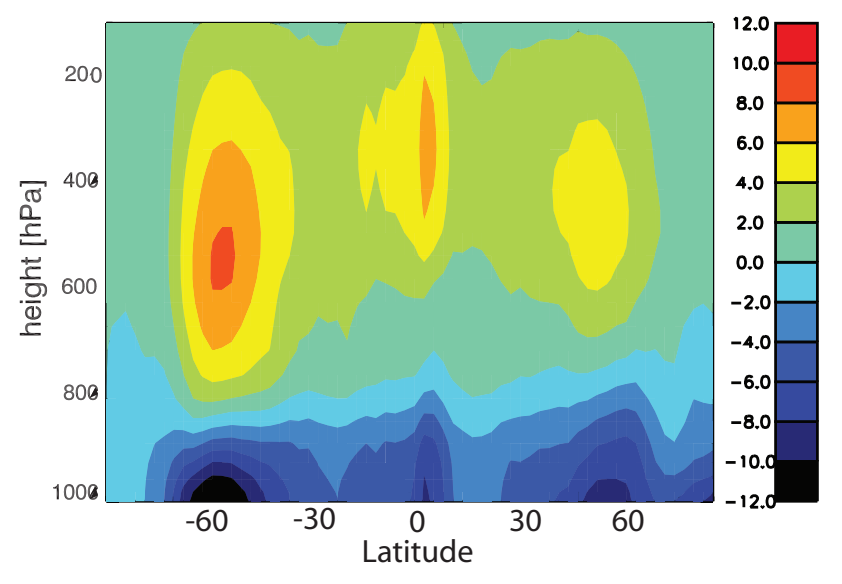

Fig. 1. Annual zonal average cloud water content (liquid+ice) from the ECMWF data (a); zonal mean percentage differences in annual mean $\mathrm{J}\left(\mathrm{NO}_{2}\right)$ (b) and $\mathrm{J}\left(\mathrm{O}^{1} \mathrm{D}\right)$ (c) between runs including clouds (REF) and omitting clouds (NOCL). 
Table 2. Annual $\mathrm{P}\left(\mathrm{O}_{3}\right), \mathrm{L}\left(\mathrm{O}_{3}\right)$, ozone burden and mass weighted mean $\mathrm{OH}$ concentration at different heights in the troposphere as calculated in the reference run (REF) and the percentage difference compared to results from the run with no clouds (NOCL).

\begin{tabular}{|c|c|c|c|c|}
\hline & $\begin{array}{l}\mathrm{P}\left(\mathrm{O}_{3}\right) \\
\mathrm{Tgyr}^{-1}(\%)\end{array}$ & $\begin{array}{l}\mathrm{L}\left(\mathrm{O}_{3}\right) \\
\mathrm{Tg} \mathrm{yr}^{-1}(\%)\end{array}$ & $\begin{array}{l}\mathrm{O}_{3} \text { Burden } \\
\mathrm{Tg}(\%)\end{array}$ & $\begin{array}{l}\text { OH Mean Conc. } \\
10^{5} \text { molec } \mathrm{cm}^{-3}(\%)\end{array}$ \\
\hline \multicolumn{5}{|l|}{ Global } \\
\hline $500 \mathrm{hPa}-$ trop & $1236(+6.3)$ & $583(+6.0)$ & $204(+1.5)$ & $8.7(+5.0)$ \\
\hline $850 \mathrm{hPa}-500 \mathrm{hPa}$ & $2407(+0.7)$ & $2458(+1.4)$ & $119(+1.0)$ & $14.8(+1.2)$ \\
\hline surface- $850 \mathrm{hPa}$ & $1697(-4.3)$ & $1682(-2.7)$ & $40(+0.7)$ & $18.0(-4.0)$ \\
\hline \multicolumn{5}{|l|}{$90 N, 20 N$} \\
\hline $500 \mathrm{hPa}-$ trop & $343(+6.2)$ & $197(+4.3)$ & $68(+1.0)$ & $8.9(+4.5)$ \\
\hline $850 \mathrm{hPa}-500 \mathrm{hPa}$ & $840(+0.5)$ & $696(+0.5)$ & $45(+0.2)$ & $13.1(+0.3)$ \\
\hline surface $-850 \mathrm{hPa}$ & $645(-4.9)$ & $427(-3.4)$ & $14(-0.4)$ & $15.7(-5.4)$ \\
\hline \multicolumn{5}{|l|}{$20 N, 20 S$} \\
\hline $500 \mathrm{hPa}-$ trop & $694(+6.0)$ & $257(+7.1)$ & $74(+1.9)$ & $9.7(+4.3)$ \\
\hline $850 \mathrm{hPa}-500 \mathrm{hPa}$ & $1256(+0.3)$ & $1412(+1.4)$ & $39(+1.3)$ & $21.1(+1.0)$ \\
\hline surface- $850 \mathrm{hPa}$ & $859(-3.7)$ & $1020(-2.4)$ & $15(+1.0)$ & $24.8(-3.5)$ \\
\hline \multicolumn{5}{|l|}{$20 S, 90 S$} \\
\hline $500 \mathrm{hPa}-$ trop & $199(+8.8)$ & $127(+5.7)$ & $63(+1.5)$ & $6.8(+4.6)$ \\
\hline $850 \mathrm{hPa}-500 \mathrm{hPa}$ & $311(+3.0)$ & $352(+3.2)$ & $35(+1.8)$ & $9.1(+3.0)$ \\
\hline surface- $850 \mathrm{hPa}$ & $195(-4.9)$ & $235(-2.9)$ & $11(+1.6)$ & $11.5(-4.1)$ \\
\hline
\end{tabular}

by clouds have a greater effect on methane than larger $\mathrm{OH}$ increases found at higher levels.

\section{Budget profile changes caused by clouds}

\subsection{Global and zonal results}

Table 2 provides a decomposition of the ozone budget to demonstrate how clouds alter photochemical activity at different altitudes in the troposphere. We focus on $\mathrm{P}\left(\mathrm{O}_{3}\right)$ and $\mathrm{L}\left(\mathrm{O}_{3}\right)$ as the key budget terms and on $\mathrm{OH}$ and ozone as the most important oxidizing species, and we use the same horizontal regions shown in Table 1 . The vertical layers are chosen to provide an insight into chemistry below, within and above clouds: (a) from the surface to $850 \mathrm{hPa}$ (corresponding to the boundary layer), (b) from 850 to $500 \mathrm{hPa}$ and (c) from $500 \mathrm{hPa}$ to the tropopause.

We find that the northern extratropics is an area of net ozone production at all levels, in contrast to the tropics and the southern extratropics. In these latter regions there is net chemical destruction in the lower and middle troposphere, but chemical production dominates at upper levels.

The effects of clouds are generally stronger for individual layers of the troposphere than for its integrated vertical extent (compare with Table 1). However, the effects are not large, and for ozone and $\mathrm{OH}$ they are smaller than suggested by Liu et al. (2006). Both $\mathrm{P}\left(\mathrm{O}_{3}\right)$ and $\mathrm{L}\left(\mathrm{O}_{3}\right)$ are reduced by up to $4.9 \%$ in the boundary layer when including clouds, whereas they increase in the middle and upper troposphere by up to $8.8 \%$. Note that for most extratropical locations production is affected more than loss. Lefer et al. (2003) used a photochemical box model coupled with a radiative transfer code to examine the effect of clouds on chemistry during the TRACE-P experiment at $20-40^{\circ} \mathrm{N}$ over the Western Pacific. They found that both $\mathrm{P}\left(\mathrm{O}_{3}\right)$ and $\mathrm{L}\left(\mathrm{O}_{3}\right)$ increased linearly with changes in photolysis rates but that production increased more quickly. Thus the modifications of photolysis rates caused by clouds are expected to affect $\mathrm{P}\left(\mathrm{O}_{3}\right)$ slightly more than $\mathrm{L}\left(\mathrm{O}_{3}\right)$.

The changes in all budget metrics in the middle troposphere are small, reflecting little change in the average effects of photolysis in this layer. One explanation for the small effect in the middle troposphere could be that higher $\mathrm{J}\left(\mathrm{O}^{1} \mathrm{D}\right)$ (leading to loss) is directly compensated by higher $\mathrm{J}\left(\mathrm{NO}_{2}\right)$ (driving production). However, both production and loss are only weakly affected in this region, so this effect is likely to be small. Another possible explanation is that the middle troposphere is a region where reflections occur between-clouds (when multiple cloud layers exist). In such cases, reductions of photolysis rates below high clouds and enhancements above low clouds could lead to very small effects in the areas between the cloud layers. However, the effect of clouds on ozone budgets is also very small in the tropical middle troposphere, a region where cumulonimbus clouds are the most common and where multi-layered clouds are found less frequently. The highest cloud water amounts are found in the middle troposphere and it is likely that the relatively small effects on the ozone budget in this region are 


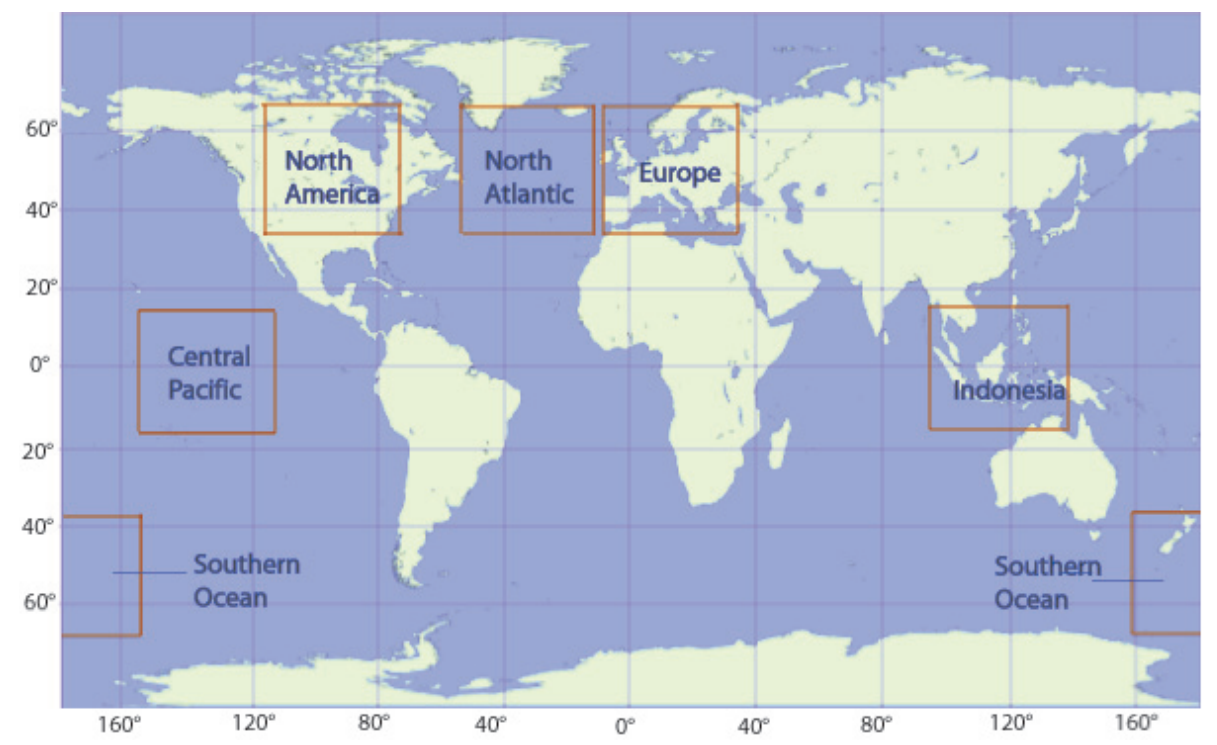

Fig. 2. Regions for which $\mathrm{P}\left(\mathrm{O}_{3}\right)$ and $\mathrm{L}\left(\mathrm{O}_{3}\right)$ profile changes are examined.

because it is a transitional zone between layers with net negative and positive effects on photolysis (see Fig. 1).

Reductions in the boundary layer are larger for $\mathrm{P}\left(\mathrm{O}_{3}\right)$ than for $\mathrm{L}\left(\mathrm{O}_{3}\right)$, both in absolute and relative terms. Increased ozone abundances in the global boundary layer are therefore unlikely to be caused by reduction in $\mathrm{L}\left(\mathrm{O}_{3}\right)$ as suggested by Liu et al. (2006). We find that this increased ozone is caused by a $3.8 \%$ increase in net downward transport into the boundary layer when including the radiative effects of clouds. Note that, since $p$-TOMCAT is an offline chemistry model, changes in the downward transport of ozone are not due to circulation changes related to clouds, but rather due to changes in the vertical ozone gradient caused by increased net production aloft.

In the upper troposphere, the increase in ozone burden is caused by increased $\mathrm{P}\left(\mathrm{O}_{3}\right)$ due largely to backscatter of radiation from cloud tops. Ozone loss also increases but by a smaller amount. Production is affected more greatly in the upper troposphere than in the boundary layer, and this may reflect the faster conversion of $\mathrm{NO}$ to $\mathrm{NO}_{2}$ at lower temperatures. Reactions of $\mathrm{NO}$ with peroxy radicals $\left(\mathrm{HO}_{2}\right.$ and $\left.\mathrm{RO}_{2}\right)$ which produce $\mathrm{NO}_{2}$ and lead to ozone production have a negative dependence on temperature.

The concentrations of $\mathrm{OH}$, which are generally largest at the lower tropical troposphere, decrease in the boundary layer due to the radiative effect of clouds, and increase in the free troposphere. The increase is more substantial in the upper than in the middle troposphere, similar to what was found for $\mathrm{P}\left(\mathrm{O}_{3}\right)$ and $\mathrm{L}\left(\mathrm{O}_{3}\right)$. There is no indication that the average effect of clouds on $\mathrm{OH}$ is significantly different in the tropics than in the extratropics.

\subsection{Changes in regional ozone production and loss}

In this section we examine the impact of clouds on ozone production and loss on a regional scale. The regions examined (see Fig. 2) are chosen to represent different atmospheric environments: Europe (9 W-34 E; 34-66 N) and North America $(73-116 \mathrm{~W} ; 34-66 \mathrm{~N})$ are northern extratropical continental regions with substantial anthropogenic sources of pollution, and we contrast these with the extratropical marine North Atlantic region $(12-55 \mathrm{~W} ; 34-66 \mathrm{~N})$. In the tropics we compare Indonesia (93-136 E; $16 \mathrm{~S}-16 \mathrm{~N}$ ), a highly convective and relatively polluted region, and the Central $\mathrm{Pa}-$ cific (113-156 W; $16 \mathrm{~S}-16 \mathrm{~N})$, representing a clean tropical oceanic location. We also consider the relatively clean environment of the Southern Ocean (160 E-157 W; 34-66 S) which has a high incidence of low cloud.

Figure 3 shows the changes in the annual mean $\mathrm{P}\left(\mathrm{O}_{3}\right)$ and $\mathrm{L}\left(\mathrm{O}_{3}\right)$ between runs including clouds (REF) and omitting them (NOCL), together with the vertical distribution of clouds. There are significant differences in cloudiness between the regions examined. The smallest cloud mass is found over northern extratropical continental areas. Over Europe, the peak around $800 \mathrm{hPa}$ is more pronounced, mainly due to the large contribution of low marine stratiform clouds along its western edge. The annual mean cloud water content over the North Atlantic is about $70 \%$ higher than over Europe and about 200\% higher than over North America. In tropical regions the cloud water content profiles show two distinct maxima, one at around $800 \mathrm{hPa}$ corresponding to shallow convection and one at $500 \mathrm{hPa}$ corresponding to deeper convection. Over the Central Pacific low altitude clouds are more frequent than over Indonesia due to more persistent shallow convection. Deep convection is important over both 


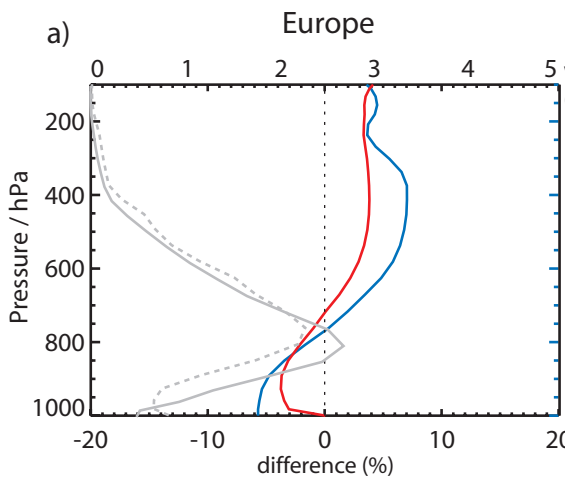

b) North America
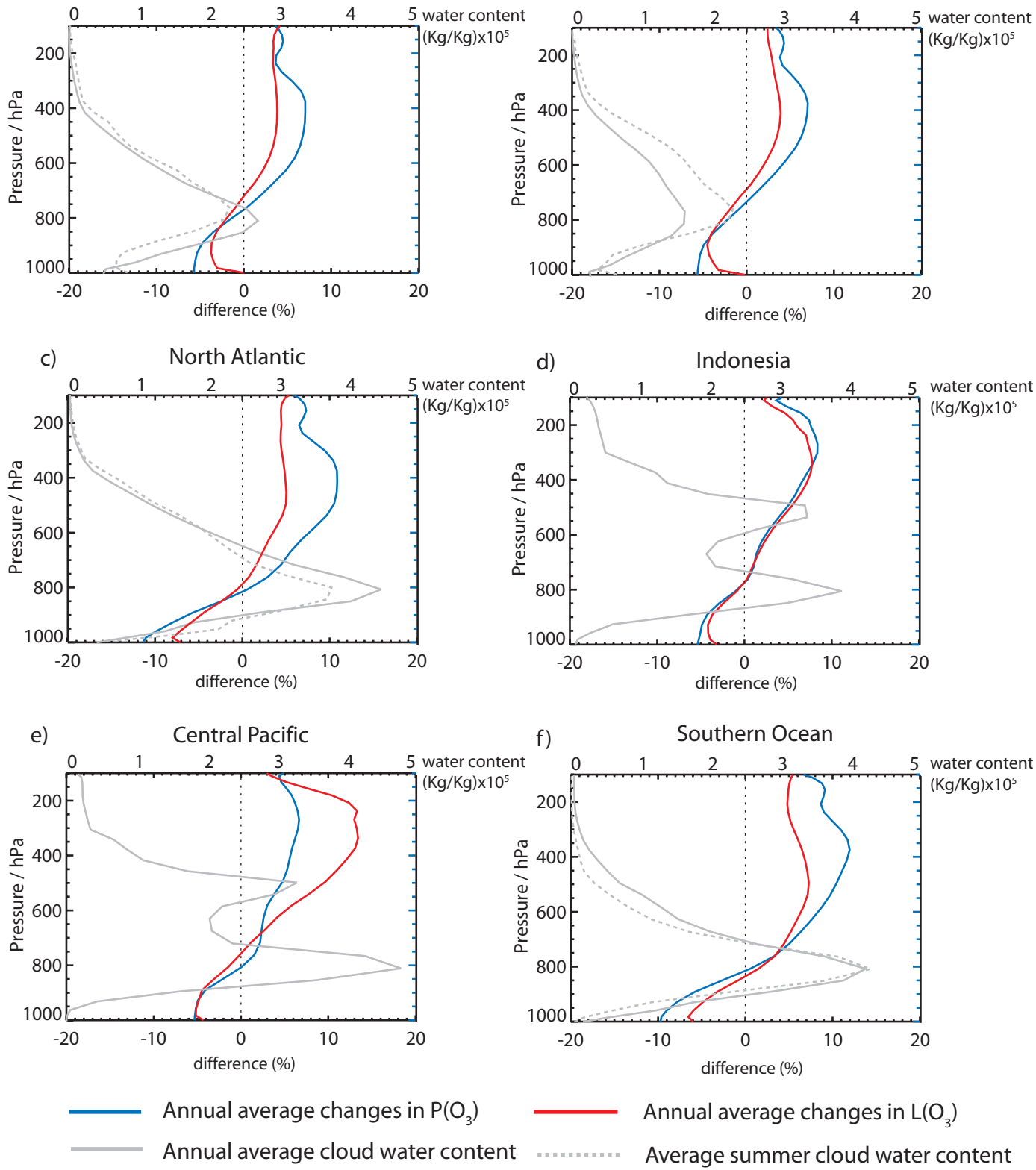

Fig. 3. Percentage differences in annual mean $\mathrm{P}\left(\mathrm{O}_{3}\right)$ and $\mathrm{L}\left(\mathrm{O}_{3}\right)$ profiles over selected regions between runs including clouds (REF) and omitting clouds (NOCL). The lower horizontal axis of each plot corresponds to the difference and the upper horizontal axis to the cloud water content.

areas, with substantial annual average water contents found even close to the tropopause. Of all the regions considered here, the largest tropospheric cloud mass is found over Indonesia. We find that cloud vertical profiles over the Southern Ocean are very similar to those over the North Atlantic.

Both $\mathrm{P}\left(\mathrm{O}_{3}\right)$ and $\mathrm{L}\left(\mathrm{O}_{3}\right)$ increase significantly above the most cloudy areas and decrease below. The main cause of this feature is that $\mathrm{J}\left(\mathrm{NO}_{2}\right)$ and $\mathrm{J}\left(\mathrm{O}^{1} \mathrm{D}\right)$ decrease below the clouds due to attenuation of radiation by cloud particles and increase above due to backscattering. The average height at which the effect of clouds shifts from negative to positive is similar for $\mathrm{P}\left(\mathrm{O}_{3}\right)$ and $\mathrm{L}\left(\mathrm{O}_{3}\right)$, about $700-800 \mathrm{hPa}$ on average. This transition point is found close to the height of maximum water content in the model, even for tropical areas, where clouds have a much greater vertical extent and their middle is much higher than is the height of maximum water content in them. This happens because solar zenith angles are small in the tropics, and it has been found that in such cases the increases in photolysis rates start at the lowest parts of clouds (Barth et al., 2002; Liu et al., 2006). 

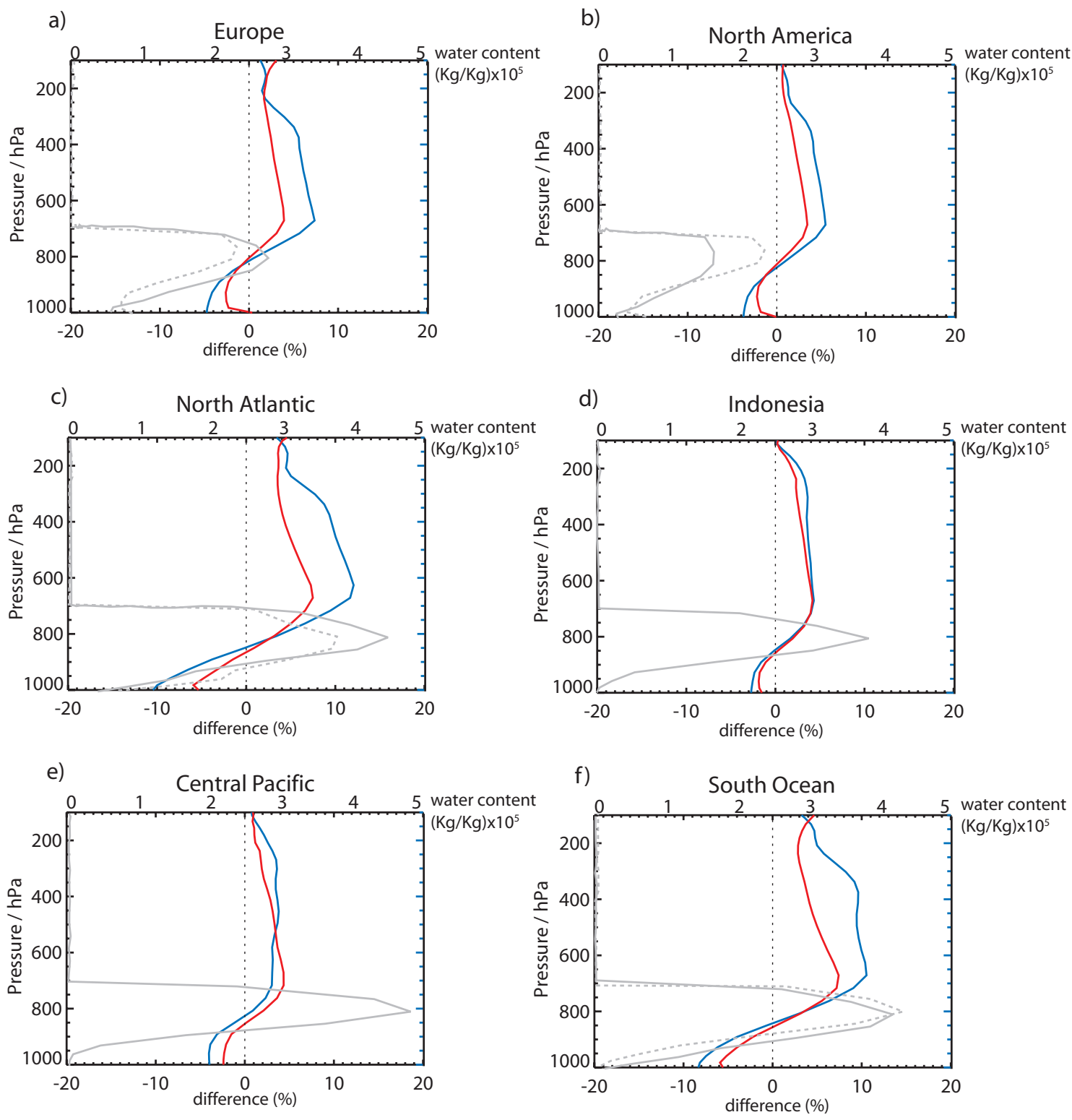

Annual average changes in $\mathrm{P}\left(\mathrm{O}_{3}\right)$

Annual average cloud water content

Annual average changes in $\mathrm{L}\left(\mathrm{O}_{3}\right)$

Average summer cloud water content

Fig. 4. Same as Figure 3 but after removing clouds above $700 \mathrm{hPa}$ from the calculations (difference between NOCL_700 and NOCL).

For Europe and North America we find that chemical tendencies show the same response to the inclusion of clouds in the model, with up to 6-7\% changes in $\mathrm{P}\left(\mathrm{O}_{3}\right)$ and up to $4 \%$ changes in $\mathrm{L}\left(\mathrm{O}_{3}\right)$, even though we find substantially greater annual mean cloudiness over Europe. However, looking at cloud water content profiles in summer (Fig. 3, grey dotted line) when photolysis is most important, it is clear that differences in cloudiness between the two regions are much smaller. Over the North Atlantic the effects are significantly more pronounced due to the greater cloudiness throughout the year. $\mathrm{P}\left(\mathrm{O}_{3}\right)$ decreases by $\pm 11 \%$ and $\mathrm{L}\left(\mathrm{O}_{3}\right)$ by $8 \%$ at the surface and above $500 \mathrm{hPa}$ the changes are up to $10 \%\left(\mathrm{P}\left(\mathrm{O}_{3}\right)\right.$ and $5 \%\left(\mathrm{~L}\left(\mathrm{O}_{3}\right)\right.$. The chemical responses to cloudiness over the Southern Ocean are very similar to those found over the North Atlantic, with slightly smaller effects at the surface and slightly larger above the clouds, particularly for $\mathrm{L}\left(\mathrm{O}_{3}\right)$.

In extratropical regions, the maximum increases in $\mathrm{P}\left(\mathrm{O}_{3}\right)$ and $\mathrm{L}\left(\mathrm{O}_{3}\right)$ above clouds occur at $400-500 \mathrm{hPa}$. For tropical locations these maxima are found higher, at $200-400 \mathrm{hPa}$, due to the larger vertical extent of tropical convective clouds. 
In the extratropics, changes in $\mathrm{P}\left(\mathrm{O}_{3}\right)$ are larger than changes in $\mathrm{L}\left(\mathrm{O}_{3}\right)$, but this feature is not seen in the tropics. Over Indonesia the responses of $\mathrm{P}\left(\mathrm{O}_{3}\right)$ and $\mathrm{L}\left(\mathrm{O}_{3}\right)$ to clouds are almost identical. The Central Pacific is the only region in which we find above-cloud enhancements in $\mathrm{L}\left(\mathrm{O}_{3}\right)$ larger than those in $\mathrm{P}\left(\mathrm{O}_{3}\right)$ (14\% compared with 8\%).

To assess the relative importance of low and high clouds in determining the features shown in Fig. 3, we performed an additional simulation in which clouds at altitudes above $700 \mathrm{hPa}$ were removed (NOCL_700). Figure 4 shows the changes in $\mathrm{P}\left(\mathrm{O}_{3}\right)$ and $\mathrm{L}\left(\mathrm{O}_{3}\right)$ caused by the low-level clouds in this calculation (NOCL_700 - NOCL). Boundary layer $\mathrm{P}\left(\mathrm{O}_{3}\right)$ and $\mathrm{L}\left(\mathrm{O}_{3}\right)$ over all regions are lower when upper-level clouds are removed, reflecting smaller total cloud optical depths in this run. The height at which the chemical tendencies change from negative to positive is $50-100 \mathrm{hPa}$ lower than in the reference run (see Fig. 3) and the largest effects are seen just above $700 \mathrm{hPa}$, reflecting the lower cloud top heights. Most of the other features are preserved: in all extratropical locations $\mathrm{P}\left(\mathrm{O}_{3}\right)$ is affected more than $\mathrm{L}\left(\mathrm{O}_{3}\right)$, while over Indonesia the changes are very similar.

Over the Central Pacific the increase in $\mathrm{L}\left(\mathrm{O}_{3}\right)$ due to clouds is significantly smaller than in the reference run. This indicates that the much larger effects on $\mathrm{L}\left(\mathrm{O}_{3}\right)$ than $\mathrm{P}\left(\mathrm{O}_{3}\right)$ above $700 \mathrm{hPa}$ in Fig. 3 are caused by the presence of middle and high-level clouds. Why this feature is not seen over Indonesia is not clear. It seems unlikely that meteorological parameters affecting chemistry cause these different responses, since temperature and humidity profiles are very similar over the two regions. However, $\mathrm{NO}_{\mathrm{x}}$ levels are much lower over the Pacific than over Indonesia, and this may be important. In addition, we have not accounted for diurnal variations in cloudiness in this study. The annual or seasonal mean cloud water contents shown here are calculated over daytime and nighttime conditions, but only daytime cloudiness influences photolysis rates. Differences between the diurnal cycles of cloudiness may contribute to the different changes in $\mathrm{L}\left(\mathrm{O}_{3}\right)$ seen over Indonesia and the Central Pacific.

We have shown that although clouds do not have a large effect on global metrics of the ozone budget, they significantly modify ozone chemistry on regional scales and at different heights in the troposphere. Variations in the chemical response to cloud radiative effects between different regions can also be important and thus caution is needed when attributing regional chemical features to cloud effects. While this analysis has focused on the annual average effects of clouds over continental scales, we expect the effects to be larger when examining smaller regions and higher temporal resolutions due to the reduced averaging involved. To demonstrate this, we show the temporal probability distribution function of two important oxidants, $\mathrm{OH}$ and ozone, at a surface location in Europe in Fig. 5. The abundance of surface $\mathrm{OH}$ is notably greater in the absence of clouds, with the probability of high $\mathrm{OH}$ (greater than $0.6 \mathrm{pptv}$ ) almost three times higher, while there is only one third of the probabil- ity of intermediate levels $(0.2-0.4 \mathrm{pptv})$. This demonstrates the strong impact of clouds on local tropospheric oxidizing capacity and the time evolution of oxidation processes. For ozone the effects are smaller, but high abundances (greater than $70 \mathrm{ppbv}$ ) are $50 \%$ more common in the absence of clouds, and low abundances (below 40 ppbv) are 20\% less common. These effects are likely to have a greater impact than the $1 \%$ increase in the average ozone abundance suggests.

To explore the effects of cloud cover on other drivers of tropospheric chemistry, we examine the differences in isoprene concentrations between runs NOCL and REF. Reaction with atmospheric $\mathrm{OH}$ provides the dominant sink of this short-lived biogenic hydrocarbon, and boundary layer concentrations over emission regions are therefore higher in the presence of cloud cover. We find that the global tropospheric isoprene lifetime, about $2.2 \mathrm{~h}$ in these model runs, increases by about $7 \%$ when including cloud cover, with the largest relative effects over the North Atlantic and areas of the Pacific with large cloud cover. This is significantly larger than the global effects on $\mathrm{O}_{3}$ and indicates the importance of cloud cover in influencing global hydrocarbon budgets. Note that over the Amazon and over Indonesia, areas with significant sources of isoprene, the increase of the boundary layer isoprene lifetime is around 5\%.

\section{Sensitivity experiments}

How does the effect of clouds compare with that of other radiatively important factors contributing to uncertainties in modelled ozone budgets? We examine the effects of cloud optical depth, surface albedo and overhead ozone column here. Wu et al. (2007) quantified the effects of large differences in zonal mean cloud extinction coefficients for GEOS3 and GEOS-4 assimilated products and for the GISS GCM. Typical differences were around 10-30\% and maximum differences of almost $100 \%$ were found in the lower tropical troposphere. Laepple et al. (2005) compared global surface albedo maps for the MOZART-2 model using different albedo parameterizations and found differences of $20 \%$ or more, even over ice-free regions such as the low latitude oceans and Africa. Previous studies have also shown differences in modelled zonal mean stratospheric ozone of 20 $25 \%$ in the tropics (Eyring et al., 2006) which will also influence tropospheric ozone budgets.

To explore how these radiatively-important factors contribute to uncertainties in the ozone budget we applied uniform $20 \%$ global perturbations to these variables. Cloud optical depths and albedos were increased by $20 \%$ (runs PERT_CL+20 and PERT_AL+20), while total overhead ozone was reduced by $20 \%$ (run PERT_O3-20). We reduced overhead ozone instead of increasing, in order to cause global photolysis increases as also expected from the albedo perturbation and possibly from the perturbation applied to clouds, 

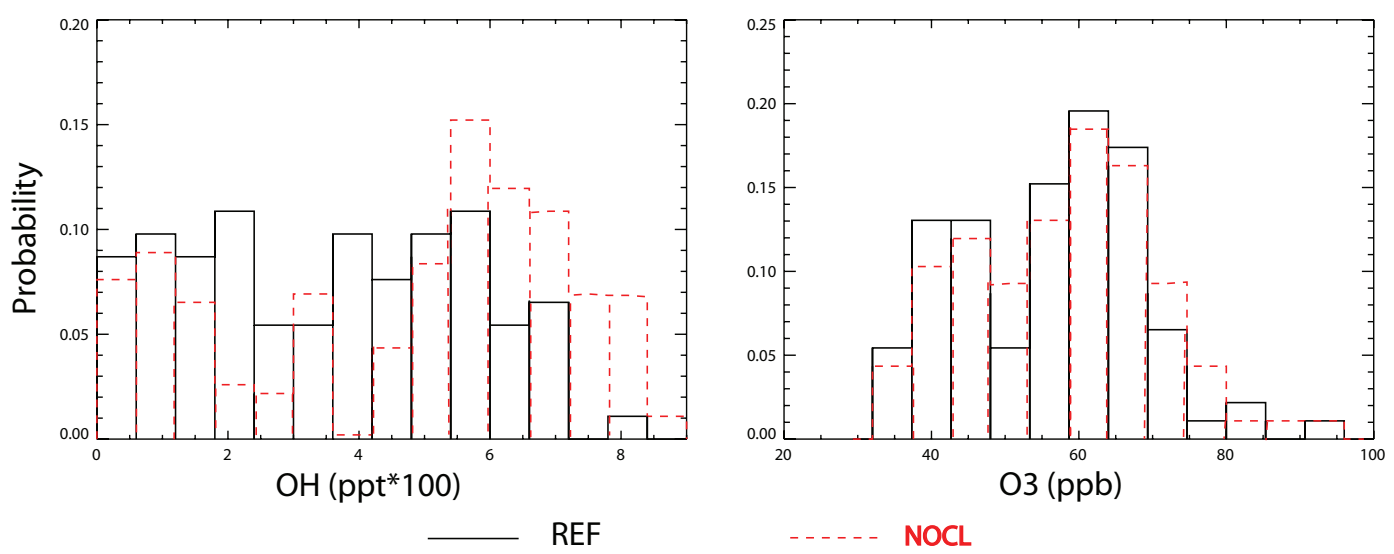

Fig. 5. Probability distribution function for 6-hourly surface $\mathrm{OH}$ and ozone at a continental European location (15 E,49 N) in summer 1997. The black bars correspond to the reference run with clouds (REF) and the red bars represent the run with no clouds in the calculations (NOCL).

based on what Section 3 suggests. The magnitude of the perturbation reflects typical uncertainties in representing clouds, surface albedos and total ozone in present-day tropospheric models. The cloud and surface albedo data are taken from the ECMWF analyses and the zonally and seasonally varying ozone column used for the radiative transfer calculations are from the monthly-mean background ozone climatology of McPeters et al. (2003). The changes in ozone column are applied only in the calculation of photolysis rates and do not affect the vertical gradient of the simulated ozone tracer in the model. Any changes in STE therefore reflect changes due to photolysis processes only.

Table 3 shows the global production, loss, deposition and transport tendencies for the three sensitivity runs and the percentage changes caused by the corresponding perturbation relative to the reference run (see Section 3). Perturbing cloud optical depths has the smallest effect on the chemical tendencies, with decreases of $0.1-0.3 \%$ in $\mathrm{P}\left(\mathrm{O}_{3}\right)$ and $\mathrm{L}\left(\mathrm{O}_{3}\right)$, and correspondingly small decreases in deposition and STE. The overall effect on the global ozone burden is minimal $(-0.3 \%)$.

The $20 \%$ increase in surface albedo has a larger influence on the global chemical budget, with $\mathrm{P}\left(\mathrm{O}_{3}\right)$ increasing by $1.3 \%$ and $\mathrm{L}\left(\mathrm{O}_{3}\right)$ by $1.5 \%$, driven by increased surface reflection. These changes are larger than those caused by clouds which involve a compensation between above and below cloud influences. The global ozone burden decreases by only $-0.5 \%$, and deposition and STE tendencies are affected little, but the methane lifetime is decreased by $3.4 \%$. Increases in $\mathrm{OH}$ caused by the increased albedo are strongest in the lower troposphere where methane oxidation is faster and for this reason the change in methane lifetime is more pronounced than the change in ozone burden.

The $20 \%$ reduction in overhead ozone affects the global budget more than changes in cloud cover and albedo: $\mathrm{P}\left(\mathrm{O}_{3}\right)$ increases by $4.1 \%$ and $\mathrm{L}\left(\mathrm{O}_{3}\right)$ by $9.3 \%$. Overhead ozone changes strongly affect tropospheric ozone photolysis, a direct loss of ozone, and therefore loss is affected more strongly than production. However, increased $\mathrm{OH}$ abundance caused by modifications of $\mathrm{J}\left(\mathrm{O}^{1} \mathrm{D}\right)$ also lead to increased ozone production via modifications of peroxy radical concentrations. The ozone burden increases in PERT_O3-20, despite increased chemical loss, but only by a small margin $(0.3 \%)$.

Although the uncertainty in representing cloud optical depths in models has little impact on the global ozone budget, the effect on smaller scales may be larger. In Table 4 we show how the $20 \%$ perturbation in cloud optical depth affects regionally averaged $\mathrm{P}\left(\mathrm{O}_{3}\right), \mathrm{L}\left(\mathrm{O}_{3}\right)$, ozone and $\mathrm{OH}$ in the boundary layer in two regions where cloudiness is found to play a particularly important role. It can be seen that the effects of the perturbation are small even at a regional scale. The presence of clouds is important for regional ozone budgets, as noted earlier, but sensitivity to the magnitude of the cloud liquid water content is much smaller. The surface albedo perturbation affects the regional budgets only to a slightly larger extent than the perturbation to cloud optical depths. The modifications of regional $\mathrm{P}\left(\mathrm{O}_{3}\right)$ and $\mathrm{L}\left(\mathrm{O}_{3}\right)$ following a perturbation to overhead ozone column are larger, but of a similar magnitude to the global modifications. However, tropospheric ozone is much more strongly affected on a regional scale when perturbing the ozone column, compared to the global effect which is very small. This implies that the positive and negative effects of this perturbation on ozone around the globe cancel out to lead to a very minimal global effect.

Comparison of global and regional effects from the cloud optical depth perturbation suggests that future changes in spatial cloud distribution as predicted by climate models may alter tropospheric chemistry significantly in a way that changes in cloud water contents do not. IPCC simulations (IPCC, 2007) project a decrease in cloud cover in the future (2080-2099) by 4\% or more over the western North Atlantic and the Mediterranean due to a northward shift of the storm 
Table 3. Sensitivity of the global annual tropospheric ozone budget (production $\mathrm{P}\left(\mathrm{O}_{3}\right)$, loss $\mathrm{L}\left(\mathrm{O}_{3}\right)$, deposition Dep., stratosphere-troposphere exchange STE, ozone burden and methane lifetime) to global 20\% perturbations in cloud optical depth (PERT_CL+20), surface albedo (PERT_AL+20) and overhead ozone (PERT_O3-20). Percentages are calculated relative to the reference run, REF.

\begin{tabular}{lllllll}
\hline & $\begin{array}{l}\mathrm{P}\left(\mathrm{O}_{3}\right) \\
\mathrm{Tg} \mathrm{yr}^{-1}(\%)\end{array}$ & $\begin{array}{l}\mathrm{L}\left(\mathrm{O}_{3}\right) \\
\mathrm{Tg} \mathrm{yr}^{-1}(\%)\end{array}$ & $\begin{array}{l}\text { Dep. } \\
\mathrm{Tg} \mathrm{yr}^{-1}(\%)\end{array}$ & $\begin{array}{l}\mathrm{STE}^{-1} \\
\mathrm{Tg} \mathrm{yr}^{-1}(\%)\end{array}$ & $\begin{array}{l}\mathrm{O}_{3} \mathrm{Burden} \\
\mathrm{Tg}(\%)\end{array}$ & $\begin{array}{l}\mathrm{CH}_{4} \text { lifetime } \\
\mathrm{yrs}(\%)\end{array}$ \\
\hline PERT_CL+20 & $5335(-0.1)$ & $4710(-0.3)$ & $1377(-0.2)$ & $737(-0.6)$ & $366(-0.3)$ & $6.71(-1.5)$ \\
PERT_AL+20 & $5409(+1.3)$ & $4777(+1.1)$ & $1383(+0.2)$ & $736(-0.6)$ & $365(-0.5)$ & $6.58(-3.4)$ \\
PERT_O3-20 & $5559(+4.1)$ & $5161(+9.3)$ & $1278(-7.4)$ & $886(+19.5)$ & $368(+0.3)$ & $6.46(-5.1)$ \\
\hline
\end{tabular}

Table 4. Sensitivity of annual tropospheric ozone production $\left(\mathrm{P}\left(\mathrm{O}_{3}\right)\right)$, loss $\left(\mathrm{L}\left(\mathrm{O}_{3}\right)\right)$, ozone burden and $\mathrm{OH}$ mean concentration in the boundary layer (below $850 \mathrm{hPa}$ ) to a $20 \%$ perturbation in cloud optical depth (PERT_CL+20), surface albedo (PERT_AL+20) and overhead ozone (PERT_O3-20). Percentage differences are relative to the reference run, REF.

\begin{tabular}{lcccc}
\hline & $\begin{array}{l}\mathrm{P}\left(\mathrm{O}_{3}\right) \\
(\%)\end{array}$ & $\begin{array}{l}\mathrm{L}\left(\mathrm{O}_{3}\right) \\
(\%)\end{array}$ & $\begin{array}{l}\mathrm{O}_{3} \text { Burden } \\
(\%)\end{array}$ & $\begin{array}{l}\text { OH Mean } \\
\text { Conc. }(\%)\end{array}$ \\
\hline $\begin{array}{l}\text { PERT_CL+20 } \\
\text { N. Atlantic }\end{array}$ & -0.9 & -0.7 & -0.1 & -0.6 \\
Indonesia & -0.8 & -0.8 & -0.1 & -0.7 \\
PERT_AL+20 & & & & \\
N. Atlantic & +0.5 & +1.2 & +0.1 & +2.0 \\
Indonesia & +1.5 & +1.3 & -0.4 & +2.1 \\
PERT_O3-20 & & & & \\
N. Atlantic & +3.9 & +12.8 & -6.2 & +17.6 \\
Indonesia & +4.6 & +8.7 & -14.0 & +13.8 \\
\hline
\end{tabular}

tracks. This shift in cloud patterns may be expected to influence the chemical processing of polluted outflow transported from the continental boundary layer. Model projections for cloud cover remain highly uncertain, and until this is addressed estimates of future changes in ozone production and tropospheric oxidation are likely to remain unreliable.

\section{Conclusions}

We have used the $p$-TOMCAT CTM to examine thoroughly the radiative role of clouds in the tropospheric ozone budget. This is a critical issue as representation of clouds is a major uncertainty in current Earth system models and the role of clouds in tropospheric photochemistry has not been clearly characterised. By looking at the regional sensitivity of ozone production and loss to cloud cover and the response of regional $\mathrm{OH}$ abundance we can learn more about the mechanisms that control tropospheric oxidizing capacity.

We find that clouds have only a minimal effect on the ozone budget and methane lifetime on a global scale. Global isoprene lifetime, however, is affected more $(+7 \%)$, which implies that clouds should be examined carefully in future studies as a factor influencing global hydrocarbon budgets, especially in the tropics. On a regional scale, the strongest effects on the ozone budget are found in the southern extratropics where marine stratiform clouds with large optical depths are dominant. The effects at different altitudes are generally much more significant (up to $14 \%$ changes) than the response integrated in the whole troposphere. The magnitude of this response is strongly dependent on geographical region.

Production of ozone is generally affected by the presence of clouds more than loss, both below and above clouds. We find an increase in global boundary layer ozone associated with cloud cover, but demonstrate that this is due to changes in downward ozone transport from the free troposphere and not to reduction in chemical loss rates below clouds as previous studies have suggested. In the upper troposphere, increased ozone is related to higher production rates due to backscattering of radiation by clouds. Changes in the middle troposphere are very small. Previous studies had speculated that compensation effects between opposite changes in $\mathrm{P}\left(\mathrm{O}_{3}\right)$ and $\mathrm{L}\left(\mathrm{O}_{3}\right)$ may be the causes of these negligible effects in this region. Here this appears not to be the explanation and we believe that what is most important is that the middle troposphere is a transitional region from negative to positive cloud effects on photolysis.

We apply a global perturbation (20\%) to cloud optical depths which reflects the uncertainty in modelling this variable, and examine how the global ozone budget is affected. The resulting changes are compared to the effects of other radiatively important factors. All global budget terms change minimally when perturbing cloud optical depths. Changes are only slightly larger when perturbing surface albedos. A global change in the overhead ozone column is found to be more important than the other perturbations. This implies that the effect of stratospheric ozone treatment on photolysis may be a major factor driving uncertainty in calculating the global tropospheric ozone budget, and significantly more important than capturing the cloud optical depths correctly.

However, clouds can be important for the ozone budget on regional scales and at different heights. Furthermore, we demonstrate that capturing the spatial patterns of cloudiness in models is more important than capturing the optical depths accurately. This suggests that studies examining global and 
regional tropospheric chemistry should focus on reproducing an appropriate distribution of cloud cover. This is particularly important for simulations of future atmospheric composition where significant changes in cloud patterns are projected.

Acknowledgements. The lead author thanks NERC (UK) and IKY (Greece) for scholarship funding. NCAS (UK) also funded this study. The authors are grateful to Paul Berrisford for providing ECMWF cloud and surface albedo data.

Edited by: S. Pandis

\section{References}

Barth, M. C., Hess, P. G., and Madronich, S.: Effect of marine boundary layer clouds on tropospheric chemistry as analyzed in a regional chemistry transport model, J. Geophys. Res., 107(D11), 4126, doi:10.1029/2001JD000468, 2002.

Chin, M., Ginoux, P., Kinne, S., Torres, O., Holben, B. N., Duncan, B. N., Martin, R. V., Logan, J. A., Higurashi, A., and Nakajima, T.: Tropospheric aerosol optical thickness from the GOCART model and comparisons with satellite and Sun photometer measurements, J. Atmos. Sci., 59, 461-483, 2002.

Evans, M. J. and Jacob, D. J.: Impact of new laboratory studies of $\mathrm{N}_{2} \mathrm{O}_{5}$ hydrolysis on global model budgets of tropospheric nitrogen oxides, ozone and OH, Geophys. Res. Lett., 32, L09813, doi:10.1029/2005GL022469, 2005.

Eyring, V., Butchart, N., Waugh, D. W., Akiyoshi, H., Austin, J., Bekki, S., Bodeker, G. E., Boville, B. A., Brühl, C., Chipperfield, M. P., Cordero, E., Dameris, N. M., Deushi, M., Fioletov, V. E., Frith, S. M., Garcia, R. R., Gettelman, A., Giorgetta, M. A., Grewe, V., Jourdain, L., Kinnison, D. E., Mancini, E., Manzini, E., Marchand, M., Marsh, D. R., Nagashima, T., Newman, P. A., Nielsen, J. E., Pawson, S., Pitari, G., Plummer, D. A., Rozanov, E., Schraner, M., Shepherd, T. G., Shibata, K., Stolarski, R. S., Struthers, H., Tian, W., and Ysohiki, M.: Assessment of temperature, trace species, and ozone in chemistry-climate model simulations of the recent past,, J. Geophys. Res., 111, D22 308, doi:10.1029/2006JD007327, 2006.

Hofzumahaus, A., Rohrer, F., Lu, K. D., Bohn, B., Brauers, T., Chang, C. C., Fuchs, H., Holland, F., Kita, K., Kondo, Y., Li, X., Lou, S. R., Shao, M., Zeng, L. M., Wahner, A., and Zhang, Y. H.: Amplified Trace Gas Removal in the Troposphere, Science, 324, 1702-1704, doi:10.1126/science.1164566, 2009.

IPCC: Climate change 2007: The physical science basis. Contribution of Working Group 1 to the Fourth Assessment Report of the Intergorvernmental Panel on Climate Change, chap. Summary for policymakers, Cambridge University Press, Cambridge, UK, 2007.

Jakob, C.: Cloud cover in the ECMWF reanalysis, J. Climc., 12, 947-959, 1999.

Krol, M. C. and VanWeele, M.: Implications of variations in photodissociation rates for global tropospheric chemistry, Atmos. Environ., 31, 1257-1273, 1997.

Laepple, T., Schultz, M. G., Lamarque, J.-F., Madronich, S., Shetter, R. E., Lefer, B. L., and Atlas, E.: Improved albedo formulation for chemistry transport models based on satellite observations and assimilated snow data and its impact on tropospheric chemistry, J. Geophys. Res., 110, D11308, doi:10.1029/2004JD005463, 2005.

Law, K. S., Plantevin, P. H., Thouret, V., Marenco, A., Asman, W. A. H., Lawrence, M., Crutzen, P. J., Muller, J. F., Hauglustaine, D. A., and Kanakidou, M.: Comparison between global chemistry transport model results and Measurement of Ozone and Water Vapor by Airbus In-Service Aircraft (MOZAIC) data, J. Geophys. Res., 105, 1503-1525, 2000.

Lefer, B. L., Shetter, R. E., Hall, S. R., Crawford, J. H., and Olson, J. R.: Impact of clouds and aerosols on photolysis frequencies and photochemistry during TRACE-P: 1 . Analysis using radiative transfer and photochemical box models, J. Geophys. Res., 108(D21), 8821, doi:10.1029/2002JD003171, 2003.

Lelieveld, J., Butler, T. M., Crowley, J. N., Dillon, T. J., Fischer, H., Ganzeveld, L., Harder, H., Lawrence, M. G., Martinez, M., Taraborrelli, D., and Williams, J.: Atmospheric oxidation capacity sustained by a tropical forest, Nature, 452, 737-740, 2008.

Liu, H., Crawford, J. H., Pierce, R. B., Norris, P., Platnick, S. E., Chen, G., Logan, J. A., Yantosca, R. M., Evans, M. J., Kittaka, C., Feng, Y., and Tie, X.: Radiative effect of clouds on tropospheric chemistry in a global three-dimensional chemical transport model, J. Geophys. Res., 111, D20303, doi:10.1029/2005JD006403, 2006.

McPeters, R. D., Logan, J. A., and Labow, G. J.: Ozone climatological profiles for Version 8 TOMS and SBUV retrievals, Eos Trans. AGU, 84, p. 46, 2003.

Neu, J. L., Prather, M. J., and Penner, J. E.: Global atmospheric chemistry: Integrating over fractional cloud cover, J. Geophys. Res., 112, D11 306, doi:10.1029/2006JD008007, 2007.

Pöschl, U., von Kulhmann, R., Poisson, N., and Crutzen, P. J.: Development and intercomparison of condensed isoprene oxidation mechanisms for global atmospheric modelling, J. Atmos. Chem., 37, 29-52, 2000.

Rohrer, F. and Berresheim, H.: Strong correlation between levels of tropospheric hydroxyl radicals and solar ultraviolet radiation, Nature, 442, 184-187, 2006.

Stevenson, D. S., Dentener, F. J., Schultz, M. G., Ellingsen, K., van Noije, T. P. C., Wild, O., Zeng, G., Amann, M., Atherton, M., Bell, N., Bergmann, D. J., Bey, I., Bulter, T., Cofala, J., Collins, W. J., Derwent, R. G., Doherty, R. M., Drevet, J., Eskes, H. J., Fiore, A. M., Gauss, M., Hauglustaine, D. A., Horowitz, L. W., Isaksen, I. S. A., Krol, M. C., Lamarque, J.-F., Lawrence, M. G., Montanaro, V., Müller, J. F., Pitari, G., Prather, M. J., Pyle, J. A., Rast, S., Rodriguez, J. M., Sanderson, M. G., Savage, N. H., Shindell, D. T., Strahan, S. E., Sudo, K., and Szopa, S.: Multimodel ensemble simulations of present-day and near-future tropospheric ozone, J. Geophys. Res., 111, D08301, doi:10.1029/2005JD006338, 2006.

Tie, X. X., Emmons, L., Horowitz, L., Brasseur, G., Ridley, B., Atlas, E., Stround, C., Hess, P., Klonecki, A., Madronich, S., Talbot, R., and Dibb, J.: Effect of sulfate aerosol on tropospheric NOx and ozone budgets: Model simulations and TOPSE evidence, J. Geophys. Res., 108, 8364, doi:10.1029/2001JD001508, 2003a.

Tie, X. X., Madronich, S., Walters, S., Y., Z. R., Rasch, P., and Collins, W.: Effect of clouds on photolysis and oxidants in the troposphere, J. Geophys. Res., 108(D20), 4642, doi:10.1029/2003JD003659, 2003 b. 
Voulgarakis, A., Savage, N. H., Wild, O., Carver, G. D., Clemitshaw, K. C., and Pyle, J. A.: Upgrading photolysis in the $p$ TOMCAT CTM: model evaluation and assessment of the role of clouds, Geosci. Model Dev., 2, 59-72, 2009.

Wild, O.: Modelling the global tropospheric ozone budget: exploring the variability in current models, Atmos. Chem. Phys., 7, 2643-2660, 2007,

http://www.atmos-chem-phys.net/7/2643/2007/.

Wild, O., Zhu, X., and Prather, M. J.: Fast-J: Accurate simulation of in- and below-cloud photolysis in Global Chemical Models, J. Atmos. Chem., 37, 245-282, 2000.
Wu, S., Mickley, L. J., Jacob, D. J., Logan, J. A., Yantosca, R. M., and Rind, D.: Why are there large differences between models in global budgets of tropospheric ozone?, J. Geophys. Res., 112, D05 302, doi:10.1029/2006JD007801, 2007.

Young, P. J., Arneth, A., Schurgers, G., Zeng, G., and Pyle, J. A.: The $\mathrm{CO}_{2}$ inhibition of terrestrial isoprene emission significantly affects future ozone projections, Atmos. Chem. Phys., 9, $2793-$ 2803, 2009,

http://www.atmos-chem-phys.net/9/2793/2009/. 